Тихонова О.В., доктор юридичних наук, профбесор кафьедри забезпечення фбінансової безпеки та фбінансового розслідування Національної академії внутрішніх справ

\title{
ПИТАННЯ КРИМІНАЛЬНОЇ ВІДПОВІДАЛЬНОСТІ ЗА ПОРУШЕННЯ БЮДЖЕТНОГО ЗАКОНОДАВСТВА УКРАЇНИ
}

\begin{abstract}
Анотація. Стаття присвячена дослідженню окремих питань кримінальної відповідальності за порушення бюджетного законодавства України. Детально розглянуті форми об'єктивної сторони злочину, відповідальність за скоєння якого передбачена ст. 210 КК України. Встановлено особливості кваліфікації за ч. 1 ст. 210 КК України у разі вчинення певних діянь. Визначено недоліки формулювання ст. 210 КК України та запропоновано шляхи їх усунення.

Ключові слова: злочин, порушення бюджетного законодавства, нецільове використання бюджетних коштів, кримінальна відповідальність, неправомірне надання кредитів з бюджету, здійснення неправомірних видатків бюджету.
\end{abstract}

Постановка проблеми. На сучасному етапі фінансова система - самостійний сегмент економіки з величезним потенціалом. Від іiі належного функціонування залежить ефективність виконання державою своїх функцій, стабільність суспільства та добробут населення країни. Суттевим складником фінансової системи є бюджетна система, яка концентрує публічні фінанси. Безпеку бюджетної системи від протиправних посягань забезпечує велика кількість суб'єктів, серед яких - Держаудитслужба України, Державна казначейська служба України, представники правоохоронних органів тощо. Водночас вона приваблює увагу багатьох злочинців, що робить її особливим об'єктом кримінально-правової охорони з боку держави. Одна 3 норм Особливої частини Кримінального кодексу України (далі - КК України) передбачає кримінальну відповідальність за порушення бюджетного законодавства - ст. 210 КК України «Нецільове використання бюджетних коштів, здійснення видатків бюджету чи надання кредитів з бюджету без встановлених бюджетних призначень або з їх перевищенням».

Аналіз останніх досліджень і публікацій. Питанням, пов'язаним 3 кримінальною відповідальністю за порушення бюджетного законодавства, у своїх наукових дослідженнях приділяли увагу П. Андрушко, М. Бажанов, Ю. Баулін, П. Берзін, Р. Волинець, О. Гладун, Н. Гуторова, Ю. Дорохіна, О. Дудоров, М. Мельник, Н. Навроцький, О. Перепелиця, В. Руфанова, І. Сікорська, В. Сташис, Р. Степанюк, Є. Стрельцов, В. Тацій, П. Фріс, М. Хавронюк, О. Шиян та інші. Проте окремі аспекти досліджуваної проблематики залишаються невисвітленими.

Метою статті $\epsilon$ висвітлення окремих особливостей диспозиції ст. 210 КК України та розроблення пропозицій щодо іï вдосконалення.

Виклад основного матеріалу. Диспозиція ст. 210 КК України побудована таким чином, що в ній описані три форми об'єктивної сторони, у якій можливе вчинення діяння, відповідальність за яке передбачена у зазначеній нормі. Об'єктивна сторона досліджуваного злочину характеризується вчиненням однієї з таких альтернативних суспільно небезпечних дій:

- нецільове використання бюджетних коштів;

- здійснення видатків бюджету без встановлення бюджетних призначень;

- здійснення видатків бюджету з їх перевищенням всупереч Бюджетному кодексу України (далі - БК України) чи закону про Державний бюджет України на відповідний рік;

- надання кредитів з бюджету без встановлених бюджетних призначень;

- надання кредитів 3 бюджету з їх перевищенням всупереч БК України чи закону про Державний бюджет України на відповідний рік.

Скоєння зазначеного злочину у формі бездіяльності, беручи до уваги закріплені законодавцем вказівки на активну форму поведінки винного «використання...коштів», «здійснення видатків...», «надання кредитів...», виключається.

Під нецільовим використанням бюджетних коштів, як визначено у ст. 19 БК України, слід розуміти витрачання на цілі, що не відповідають: бюджетним призначенням, встановленим законом про Державний бюджет України (рішенням про місцевий бюджет); напрямам використання бюджетних коштів, визначеним у паспорті бюджетної програми (у разі застосування програмно-цільового методу у бюджетному процесі) або в порядку використання бюджетних коштів; бюджетним асигнуванням (розпису бюджету, кошторису, плану використання бюджетних коштів).

Своєю чергою нецільове використання бюджетних коштів, як зазначає О. Дудоров, може набувати вигляду: а) фінансування за рахунок бюджетних коштів тих видатків, які не передбачені видатковими статтями затвердженого бюджету (наприклад, спрямування бюджетних коштів на придбання різноманітних активів - валюти, цінностей, іншого майна 3 метою отримання прибутків та (або) наступного продажу, здійснення за рахунок бюджетних коштів внесків до статутних фондів господарських товариств або надання благодійної допомоги); б) використання бюджетних коштів, що мали цільове спрямування, з іншою метою, тобто фінансування одних видатків за рахунок інших статей видатків (наприклад, фінансування виробництва за рахунок коштів, призначених для виплати заробітної плати; використання на утримання державних органів коштів, виділених на фінансування заходів у сфері освіти; витрачання бюджетних коштів, виділених для усунення аварії на шахті та надання допомоги сім'ям загиблих, на погашення банківських кредитів та заборгованості з виплати заробітної плати) [1, с. 626].

Розглядаючи зазначену форму прояву, слід звернути увагу на необхідність вирізняти видатки, що становлять Державний 
бюджет України від видатків, що становлять резервний фонд бюджету, який згідно зі ст. 24 БК України формується для здійснення непередбачених видатків, що не мають постійного характеру і не могли бути передбачені під час складання проекту бюджету. Порядок використання коштів з резервного фонду бюджету визначається Кабінетом Міністрів України [2]. БК України розрізняє нецільове використання бюджетних коштів i порушення вимог закону щодо виділення коштів з резервного фонду бюджету, у зв'язку з чим у разі фінансування заходів, які згідно з п. 7 Порядку використання коштів резервного фонду бюджету, затвердженого постановою Кабінету Міністрів України від 29 березня 2002 р. № 415, не можуть фінансуватися за рахунок коштів резервного фонду, варто за наявності на те інших підстав зазначені дії кваліфікувати за ст. 364 КК України чи 367 КК України.

Другою та третьою формами цього злочину є здійснення видатків бюджету без встановлених бюджетних призначень або з їх перевищенням усупереч БК чи закону про Державний бюджет України на відповідний рік, які являють собою спрямування коштів на здійснення програм та заходів, що не передбачені бюджетними призначеннями, встановленими законом про Державний бюджет України на відповідний рік (рішенням про місцевий бюджет) всупереч БК України або 3 перевищенням меж цих призначень. Слід враховувати, що до видатків бюджету (відповідно до п. 13 ч. 1 ст. 2 БК України) не належать: погашення боргу; надання кредитів з бюджету; розміщення бюджетних коштів на депозитах; придбання цінних паперів; повернення надміру сплачених до бюджету сум податків і зборів (обов'язкових платежів) та інших доходів бюджету, проведення їх бюджетного відшкодування.

Ці форми прояву злочину, передбаченого ст. 210 КК України, відрізняються від попередньої тим, що вони характеризуються здійсненням видатків бюджету за відсутності на це бюджетних призначень взагалі або ж за наявності, але 3 їх перевищенням. 3 цього витікає, що у разі здійснення видатків 3 бюджету за наявності та в межах бюджетних призначень, але 3 порушенням, зокрема паспортів бюджетних програм, розписів бюджетів, кошторисів, планів використання бюджетних коштів їх одержувачами, зазначені дії не охоплюються такою формою об' єктивної сторони розглядуваного злочину, а мають кваліфікуватися як нецільове використання бюджетних коштів. Наприклад, «використання на утримання місцевого органу виконавчої влади відділу освіти районної державної адміністрації коштів з місцевого бюджету» [3]. Відзначимо, що у зазначених випадках видатки мають здійснюватися з Державного бюджету України, а не з місцевого, у зв'язку з чим такі дії кваліфікуються як здійснення видатків з місцевого бюджету без встановлених відповідних бюджетних призначень усупереч БК України та закону про Державний бюджет на відповідний рік. Якщо $з$ відповідного місцевого бюджету здійснюються видатки, які мають проводитися згідно з БК України з іншого бюджету, такі дії є нецільовим використанням бюджетних коштів. Зазначимо, що така форма прояву нецільового використання бюджетних коштів є досить поширеною [4; 5; 6].

Слід також мати на увазі, що перевищення асигнувань може мати місце в разі здійснення розрахунків за господарськими операціями поза казначейською системою, таких як взаємозаліки або отримання благодійної допомоги тощо, і невнесення при цьому змін до планових показників кошторису. Але за цих обставин у ст. 116 БК України передбачається близько сорока випадків можливих порушень. Зокрема, у такій ситуації можливе трактування як взяття зобов'язань без відповідних бюджетних асигнувань або з перевищенням повноважень, установлених БК України чи законом про Державний бюджет (п. 20 ч. 1 ст.116 БК України), або здійснення платежів за рахунок бюджетних коштів без реєстрації бюджетних зобов'язань, за відсутності підтвердних документів чи у включенні до платіжних документів недостовірної інформації (п. 23 ч. 1 ст. 116 БК України) з відповідними наслідками, визначеними ст. 117 БК України. У зв'язку з цим прийняття рішення про встановлення факту нецільового використання бюджетних коштів, як правильно зазначає О. Чечуліна, потребує детального аналізу всіх стадій бюджетного законодавства, починаючи від розрахунків до кошторису та завершуючи інформацією про виконання паспорта бюджетної програми (або програм і заходів з виконання повноважень органів влади, державних адміністрацій та органів самоврядування) [7, с. 22].

Наступними формами прояву злочину, передбаченого ст. 210 КК України, є надання кредитів з бюджету без встановлених бюджетних призначень або з їх перевищенням усупереч БК чи закону про Державний бюджет України на відповідний рік, які полягають у порушенні встановленого чинним законодавством порядку надання кредитів.

Зазначимо, що згідно 3 п. 31 ч. 1 ст. 2 БК України кредитування бюджету - це операції з надання коштів з бюджету на умовах повернення, платності та строковості, внаслідок чого виникають зобов'язання перед бюджетом (надання кредитів 3 бюджету) та операції з поверненням таких коштів до бюджету (повернення кредитів до бюджету). Для цілей БК України до кредитів з бюджету також належать бюджетні позички та фінансова допомога з бюджету на поворотній основі [8, с. 301].

Згідно зі ст. 23 БК України і Порядку передачі бюджетних призначень, перерозподілу видатків бюджетів і надання кредитів з бюджету, затвердженого Постановою КМУ від 12 січня 2011 р. №18, надання кредитів з бюджету за бюджетними програмами у межах загального обсягу бюджетних призначень, передбачених головному розпоряднику бюджетних коштів, здійснюється за рішенням Кабінету Міністрів України (місцевої державної адміністрації, виконавчого органу відповідної місцевої ради), погодженим із Комітетом Верховної Ради України з питань бюджету (відповідною комісією місцевої ради) [9]. Слід зазначити, що надання кредитів у межах загального обсягу бюджетних призначень за бюджетними програмами, але без проходження відповідної процедури, описаної вище, з огляду на порушення порядку надання кредитів з бюджету, слід кваліфікувати як нецільове використання бюджетних коштів. На чому наголошувалося і в юридичній літературі [8, с. 302].

Якщо службовій особі не вдалося використати бюджетні кошти всупереч їх цільовому призначенню або здійснити видатки бюджету без установлених бюджетних призначень або 3 їх перевищенням усупереч закону через те, що орган Державної казначейської служби України, перевіривши платіжне доручення і підтвердні документи, відмовився оплатити рахунок розпорядника (одержувача) бюджетних коштів, учинене за спрямованістю умислу треба кваліфікувати за відповідними частинами ст. ст. 15 і 210 КК як замах на цей злочин, оскільки останній не було доведено до кінця з причин, що не залежали від волі особи. В іншому випадку, відповідаючи на риторичне 
запитання О. Чечуліної, чому розпорядник бюджетних коштів залишається єдиною винною особою [7, с. 20], з огляду на зміст ч. 5 ст. 48 БК України щодо відповідальності Державної казначейської служби України, що у разі реєстрації та обліку бюджетних зобов'язань здійснює перевірку відповідності напрямів витрачання бюджетних коштів асигнуванню, паспорту бюджетної програми, дії службової особи Державної казначейської служби України мають підлягати кримінально-правовій оцінці, зокрема на предмет наявності ознак злочину, передбаченого ст. 367 КК України.

Видання керівником бюджетної установи наказу про використання бюджетних коштів усупереч їх цільовому призначенню або про здійснення видатків бюджету без установлених бюджетних призначень або з їх перевищенням усупереч закону, а так само оформлення необхідних документів - платіжного доручення і підтвердних документів, не виходить за межі умисного створення умов для скоєння злочину, а тому має розглядатись як готування до злочину, передбаченого ч. 2 ст. 210 КК України.

Не зважаючи на те, що вчинення особою однієї дії, яка містить ознаки декількох передбачених ч. 1 ст. 210 КК України порушень бюджетного законодавства, на кваліфікацію злочину не впливає [8, с. 302], вони підлягають обов'язковому встановленню та відображенню в судовому рішенні, а також для дотримання принципу індивідуалізації покарання має враховуватися у його призначенні. При цьому у разі продовжуваного злочину (тобто, коли вчинення двох або більше окремих порушень бюджетного законодавства охоплювалось єдиним умислом особи) розмір бюджетних коштів встановлюється 3 урахуванням їх загальної суми.

Окрім того, слід звернути увагу на невідповідність диспозиції ч. 1 ст. 210 КК України змісту п. 1 примітки до цієї статті, зокрема в частині приналежності бюджетних коштів процесуальному порядку. Так, у п. 1 примітки до ст. 210 КК України зазначається, що до бюджетних коштів належать кошти, що включаються до державного бюджету і місцевих бюджетів незалежно від джерела їх формування. При цьому державний бюджет затверджується відповідно до п. 24 ч. 1 ст. 2 БК України законом про Державний бюджет України, а місцевий бюджет, згідно п. 45 ч. 1 ст. 2 БК України, рішенням про місцевий бюджет. У зв'язку з цим, беручи до уваги наявне у диспозиції ч. 1 ст. 210 КК України посилання, окрім БК України, лише на закон про Державний бюджет України, є таким, що не відображає змістову частину складу зазначеного злочину, а тому доцільним видається доповнення ч. 1 ст. 210 КК після слів «на відповідний рік» словами «рішенням про місцевий бюджет».

Водночас, якщо звернутись до назви ст. 210 КК України «Нецільове використання бюджетних коштів, здійснення видатків бюджету чи надання кредитів з бюджету без встановлених бюджетних призначень або з їх перевищенням», привертає увагу ії зайве перевантаження. Не зовсім зрозуміло позицію законодавця, який намагався у назві статті відтворити всі форми об'єктивної сторони злочинного діяння, за яке нею передбачена кримінальна відповідальність. Крім того, інші форми порушення бюджетного законодавства не підпадають під дію зазначеної статті. На наш погляд, доцільним є спростити назву ст. 210 КК України та викласти її у такій редакції: «Порушення бюджетного законодавства», адже поняття «бюджетне законодавство» (відповідно до ст. 4 БК України) вміщує цілу низку нормативно-правових актів. Зокрема, Конституцію України, Бюджетний кодекс України, закон України про Державний бюджет України, інші закони, що регулюють бюджетні відносини, нормативно-правові акти Кабінету Міністрів України, прийняті на підставі і на виконання положень БК України тощо.

Висновки. Отже, ст. 210 КК України «Нецільове використання бюджетних коштів, здійснення видатків бюджету чи надання кредитів 3 бюджету без встановлених бюджетних призначень або з їх перевищенням» далека від досконалості, що викликає певні труднощі у застосуванні їі окремих положень. Саме це зумовлює необхідність іiі доопрацювання та внесення відповідних змін.

\section{Jimepamypa:}

1. Науково-практичний коментар Кримінального кодексу України / за ред. М.І. Мельника, М.І. Хавронюка. 9-те вид., переробл. та допов. К.: Юридична думка, 2012. 1316 с.

2. Про затвердження Порядку використання коштів резервного фонду бюджету: Постанова Кабінету Міністрів України від 29 бер. 2002 p. № 415. URL: http://zakon2.rada.gov.ua/laws/show/415-2002$\% \mathrm{D} 0 \% \mathrm{BF} /$ paran 11

3. Вирок Нововоронцовського районного суду Херсонської області від 30 квіт. 2013 р. у справі № 2116/1326/2012. URL: http://www. reyestr.court.gov.ua/Review/31038399

4. Вирок Каховського міськрайонного суду Херсонської області від 05 верес. 2013 р. у справі № 658/3407/13-к. URL: http://www. reyestr.court.gov.ua/Review/33551021

5. Постанова Генічеського районного суду Херсонської області від 15 жовт. 2012 р. у справі № 2107/1742/2012. URL: http://www. reyestr.court.gov.ua/Review/26847548

6. Постанова Скадовського районного суду Херсонської області від 21 черв. 2012 р. у справі № 2119/1718/12. URL: http://www.reyestr. court.gov.ua/Review/26786676

7. Чечуліна О. Нецільове використання? Та ні, цільове! Баланс-бюджет: бюджетний процес. 2014. № 44 (508). 3 лист. 2014 р. C. $18-22$.

8. Кримінальний кодекс України. Науково-практичний коментар: у 2 т. / за заг. ред. В.Я. Тація, В.П. Пшонки, В.І. Борисова, В.І. Тютюгіна. 5-те вид., допов. Х. : Право, 2013. Т. 2: Особлива частина / Ю.В. Баулін, В.І. Борисов, В.І. Тютюгін та ін. 2013. 1040 c.

9. Порядок передачі бюджетних призначень, перерозподілу видатків бюджету і надання кредитів з бюджету: Постанова Кабінету Міністрів України від 12 січ. 2011 р. № 18. URL: http://zakon2.rada.gov. ua/laws/show/18-2011-\%D0\%BF

Тихонова Е. В. Вопросы уголовной ответственности за нарушения бюджетного законодательства Украины

Аннотация. Статья посвящена исследованию отдельных вопросов уголовной ответственности за нарушение бюджетного законодательства Украины. Детально рассмотрены формы объективной стороны преступления, ответственность за совершение которого предусмотрена ст. 210 УК Украины. Установлены особенности квалификации по ч. 1 ст. 210 УК Украины при совершении отдельных деяний. Определены недостатки формулировки ст. 210 УК Украины и предложены пути их устранения.

Ключевые слова: преступление, нарушение бюджетного законодательства, нецелевое использование бюджетных средств, уголовная ответственность, неправомерное предоставление кредитов из бюджета, осуществление неправомерных расходов бюджета. 
Tykhonova $O$. The criminal responsibility issue of budget legislation violations of Ukraine

Summary. The article investigates specific issues of criminal liability for violation of budget legislation of Ukraine. We discussed in detail form the objective side of the offense, liability for which is provided by Art. 210 of the Criminal Code of Ukraine. The specifics of qualifications under Part 1 of Art. 210 of the Criminal Code of Ukraine in the commission of individual acts. Were identified shortcomings of the wording of Art. 210 of the Criminal Code of Ukraine and suggested ways to eliminate its.

Key words: crime, violation of budget legislation, inappropriate use of budget funds, criminal liability, illegal provision of loans from the budget, implementation of illegal budget expenditures. 